apply when the rights of an infant injured while en ventre sa mère are under consideration, for the child has been guilty of no wrong or omission. Otherwise a great injustice might be done if financial protection were to be denied to a youngster who may have suffered a permanent injury.

\title{
CONSIDERATION OF PUNISHMENT BY JURIES
}

It is frequently stated that juries in criminal cases are to determine the question of guilt or innocence from the evidence alone and that a consideration of the severity of the penalty to be imposed should not influence their verdict. ${ }^{\mathrm{I}}$ Observance of this rule is essential to the preservation of the doctrine of "reasonable doubt, ${ }^{\prime \prime 2}$ since the slightest consideration of a light sentence or of a quick parole may exert just the degree of influence necessary to persuade the doubtful juror to agree to a verdict of guilty. ${ }^{3}$ Moreover, since juries are not to be judges of the law, 4 they should not be given the opportunity to decide that

other, (2) it is unfair to allow a party to recover for his own wrong, and (3) it is a policy of the law to make the personal interests of the parties dependent upon their own prudence and care.

I People v. Sherman, 264 App. Div. 274, 35 N.Y.S. 2d I7I (I942); People v. Warner, 289 Mich. 516, 286 N.W. 8 II (1939); State v. Doucet, 177 La. 63, I47 So. 500 (1933); State v. Lunsford, I63 Wash. I99, 300 Pac. 529 (I93I); State v. Bell, 206 Iowa 8I6, 22 I N.W. 52I (I928); People v. Santini, 22I App. Div. 139, 222 N.Y. Supp. 683 (1927); Liska v. State, Ir 5 Ohio St. 283, I52 N.E. 667 (I926); State v. Kernan, I54 Iowa 672, I35 N.W. 362 (r9I2); State v. Satcher, I24 La. xoI5, 50 So. 835 (rgog); State v. Gill, I4 S.C. 4 Io (1880).

2 A well known definition of the term "reasonable doubt" is that expressed by Chief Justice Shaw in Commonwealth v. Webster, 5 Cush. (Mass.) 295, 320 (1850). It is "that state of the case, which, after the entire comparison and consideration of all the evidence, leaves the minds of jurors in that condition that they cannot say they feel an abiding conviction, to a moral certainty, of the truth of the charge.... The evidence must establish the truth of the fact to a reasonable and moral certainty - a certainty that convinces and directs the understanding and satisfies the reason and judgment. ..."

It is stated in Wigmore, however, that this degree of certainty is an "elusive and undefinable state of mind." He suggested that all efforts toward definition be abandoned and that juries be left to apply "reasonable doubt" as words of common usage. 9 Wigmore, Evidence $\$ 2497$ (3d ed. I940).

3 "[Considering] that a very slight circumstance may affect the verdict, the danger from putting before the jury anything that may improperly influence their deliberations becomes more apparent." Miller v. United States, 37 App. D.C. r38, r44 (rgrI). If the jury receives the impression that the penalty may not be serious, such impression will be almost certain to affect the verdict in doubtful cases.

4 A. L. I. Code of Crim. Proc. $\$ 323$ (I93I); 23 C.J.S. Criminal Law $\S$ III8, at 6 I6 n. 57 , 58 (I940). To an extent the right to bring in a general verdict gives to a jury the power to determine the law as well as the facts by acquitting a defendant in opposition to the court's instructions on the law. If this power is improperly exercised, the error is not remediable, since a defendant may not be tried twice for the same crime. It is usually stated that a jury has the power to disregard the law as explained by the court, but not the moral right to do so. Commonwealth v. Castellana, $277 \mathrm{~Pa}$. II7, I2I Atl. 50 (I923); Brown v. Commonwealth, 86 Va. 466 , xo S.E. 745 (I89o); I6 C.J. Criminal Law $\$ 2273$, at $922 \mathrm{n} .2$ (r9I8). In some jurisdictions, however, it has been held that it is legally permissible for a jury to disregard a court's instructions on the law, and that the judge may give an instruction to this effect. Hengstler v. State, 
the punishment for a particular crime is too severe and, therefore, to acquit a defendant of whose guilt they are convinced. The ability of a jury to disregard the law has long been regarded as the chief justification for jury trials in criminal cases, ${ }^{5}$ but the reasoning in support of this view does not apply to punishment. ${ }^{6}$ An examination of the powers given to juries in many jurisdictions, however, indicates that very often they are permitted to speculate on, and even to determine, the punishment to be inflicted. The necessary separation of the question of punishment from the determination of the defendant's guilt or innocence has therefore become increasingly difficult, if not psychologically impossible.

Juries in six states are authorized by statute to accompany their verdicts in criminal cases with a recommendation of mercy $;^{7}$ other jurisdictions permit such recommendations to be made even though no statutory authority has been conferred. ${ }^{8}$ In order that a jury may not be led to believe that a recommenda-

85 Ind. 538, 189 N.E. 623 (1934); Bryant v. State, 205 Ind. 372 , 186 N.E. 322 (1933); I6 C.J. Criminal Law $\$ 2273$, at $922 \mathrm{n}$. 95,96 ( $(9 \mathrm{~g} 8$ ). An Illinois statute making juries judges of the law as well as the facts was held unconstitutional. People v. Bruner, 343 Ill. I46, I75 N.E. 400 (193r).

${ }^{5}$ Historically the ability of a jury to disregard the law by means of a general verdict has been the main reason why trial by jury is now regarded as a basic political right. Under the Stuarts in England trial by jury in criminal cases was an important safeguard against harsh laws and oppressive administration. Prior to the American Revolution the dispensing power of juries was regarded as an important protection against the enforcement of obnoxious legislation by royal governors. "Thus, from the beginning of American Law, we bave thought of the jury in terms of ... eighteenth-century contests between the colonies and royal authority, rather than as an effective tribunal for ascertainment of the facts in criminal prosecutions." Nat'l Com. on Law Observance and Enforcement, Report on Crim. Procedure 23-28 (193I).

At least one eminent authority has stated that the ability of juries to disregard the law is the main reason for preserving trial by jury in criminal cases, since the general verdict allows for the necessary flexibility of legal rules when the law can not concede that the application of the general rule may work an injustice in a particular case. Wigmore, A Program for the Trial of Jury Trial, I2 J. Am. Jud. Soc. I66 (I929). Another point of view, however, is that juries, by disregarding the law, greatly abuse the general verdict. "If any legal rules are too harsh, or for any reason undesirable, let us change them by statute. ... It is surely folly to pretend to keep legal rules and leave their amendment or nullification to a series of legislatures each consisting of twelve men casually selected as jurors." Frank, If Men Were Angels 88 (I942). Both views can probably be reconciled by saying that juries should not disregard the law because they feel that it is undesirable, but that it is proper for them to set aside the generally desirable rule of law if it results in an injustice in a particular case. There is, of course, no way to assure that a jury will exercise its dispensing power in accordance with this distinction.

${ }^{6}$ The injustice of a general rule when applied to a specific case may well be a matter for the determination of a body representing a cross-section of the community. Wigmore, op.cit. supra note 5 at $\mathrm{r} 66$. But it does not follow that juries should be permitted to set aside the law because they feel that a particular penalty is too severe. Since punishment is now being determined on a more individual basis, the disposition of offenders is a problem for specialists in criminology and psychiatry. See infra note 27.

${ }^{7}$ Del. Rev. Code (I935) § 5330; Fla. Stat. (I94I) § 9rg.23(I); Ga. Code (1948) § 27-250I; N.M. Stat. Ann. (194I) § 42-I302; Tenn. Code Ann. (Michie, I938) § Io772; Utah Rev. Stat. Ann. (I933) \& 103-28-4. Under these statutes recommendations by the jury are merely advisory; the court's discretion in fixing the punishment is in no way limited.

${ }^{8}$ It is the prevailing view that in the absence of statute the jury has no right to recommend mercy, but courts usually permit such recommendations to be made and treat them as sur- 
tion of leniency will automatically reduce the punishment and thereby justify them in convicting a defendant whose guilt has not been proved beyond a reasonable doubt, it is important that a trial court exercise great caution when instructing the jury as to the effect of a recommendation. Unfortunately, the cases indicate that frequently the proper degree of care is not exercised and that appellate courts are often very lenient in upholding cases in which the trial court's instructions regarding the jury's right to recommend mercy might well have induced a verdict of guilty.

In Warford v. State, 9 for example, the testimony was conflicting, and the jury, after failing to reach a verdict, returned to the court room to inquire whether the defendant, if found guilty, could be given a suspended sentence. The judge replied that the jury could make a recommendation to that effect, and he strongly intimated that any recommendation they made would be followed. ${ }^{x}$ But when the jury returned a verdict of guilty and recommended suspension of sentence, the court refused to comply. On appeal, the defendant claimed that he had been seriously prejudiced since the judge had improperly induced a conviction by leading the jury to believe that a suspended sentence would be granted. The Arkansas Supreme Court nevertheless refused to reverse, stating that the judge was not legally bound to abide by the jury's recommendation, that the court's instructions did not constitute a promise to that effect, and that, even if they had, they could not be assigned as error since counsel for the defense had failed to register an objection at the trial. ${ }^{\text {x }}$ Two members of the court dissented on the ground that although the trial judge may not have directly promised that he would suspend sentence, it seemed certain that this was the inference made by the jury and that their verdict was undoubtedly induced by this belief.

The authorities indicate clearly that a court's promise or direct implication that it will show mercy is reversible error, since it will be considered an induce-

plusage. They are advisory only and do not affect the validity of the verdict. See Annotations: I7 A.L.R. III7, II56, II6I-64 (1922); 87 A.L.R. I362, I370, 1372-74 (1933); I38 A.L.R. I230, I245, I250-53 (I942).

${ }_{9} 2 \mathrm{I} 6 \mathrm{~S}$.W. $2 \mathrm{~d} 78 \mathrm{I}$ (Ark., I949). The defendant was being tried for rape and carnal abuse, the penalty for which ranged from one year's imprisonment to death. Ark. Stat. (Pope, I937) $\S \S 3405,3406$.

ro "I have been making it a practice ... if anybody is tried by a jury then I will let the verdict of the jury stand unless the jury makes recommendations."

Ir The rule that appellate courts will not consider matters which the defendant failed to raise below has been criticised in its application to criminal cases on the ground that the concept of a fair trial demands that the defendant's complaints be considered strictly on their merits. The assurance that no defendant will be convicted without a fair trial should not be sacrificed to demands for procedural efficiency, and it has been suggested that courts might better follow the procedure, already adopted in some jurisdictions, which permits appellate courts to review the entire record and to reverse whenever they feel that justice so requires. Appellate Review in Criminal Cases of Points Not Raised Below, 54 Harv. L. Rev. 1204, I213 (I94); A. L. I. Code of Crim. Proc. $\$ 457$ (r) (r93r). 
ment for a verdict of guilty when the jury is in doubt..$^{22}$ Very often, however, in answer to inquiries similar to that made by the jury in the Warford case, judges, instead of directly intimating what the effect of a recommendation would be, have given ambiguous answers which may or may not have been misleading. Juries have been told, for example, that their recommendations would be given due consideration; ;3 $^{\text {or }}$, where juries have asked if they could recommend leniency, courts have frequently answered "yes," but without adding that a recommendation would not be binding. ${ }^{4}$ The authorities are about evenly divided as to whether such statements constitute error. One line of cases holds that it should not be assumed that jurors disregard their oaths and allow considerations of a possible lenient sentence to induce them to agree to a verdict of guilty. ${ }^{15}$ The cases which declare that such instructions do constitute error, on the other hand, assert that statements of this sort are well calculated to influence the verdict in doubtful cases, in which jurors often convict if they think that the penalty will be light. ${ }^{16}$ It is impossible, of course, to determine whether in the cases cited any juror actually was persuaded to agree to a verdict of guilty because he believed that a recommendation of mercy would affect the sentence. But in each

12 Pendleton v. State, 2xi Ark. 1054, 204 S.W. 2d 559 (I947); People v. Lynch, 284 N.Y. 239, 30 N.E. 2 d 577 (1940); People v. Santini, 221 App. Div. I39, 222 N.Y. Supp. 683 (1927); Bethel v. State, 162 Ark. 76, 257 S.W. 740 (1924); Pittman v. State, 84 Ark. 292, I05 S.W. 874 (1907); State v. Kiefer, 16 S.D. I80, 9I N.W. III7 (1902) (the judge stated that he had made it an invariable rule to follow the jury's recommendations); McBean v. State, 83 Wis. 206, 53 N.W. 497 ( 1892 ) (in answer to the jury's question "if we bring in a verdict of guilty, can we depend on the clemency of the court?" the judge answered "yes").

${ }_{33}$ United States v. Parker, I03 F. 2d 857 (C.C.A. 3d, I939); State v. Doucet, I77 La. 63, 147 So. 500 (1933); State v. Sweat, 159 La. 769, 106 So. 298 (I925); State v. Knight, 34 N.M. 222, 279 Pac. 947 (I929); State v. Kernan, 154 Iowa 672, 135 N.W. 362 (I9I2); Territory v. Griego, 8 N.M. I33, 42 Pac. 8 I (I895); State v. Murrel, 33 S.C. 83 , II S.E. 682 (I89o).

14 United States v. Krulewitch, 167 F. 2 d 943 (C.C.A. 2d, 1948); State v. Rowell, 224 N.C. 768, 32 S.E. 2 d 356 (I944); James v. State, 77 Okla. Cr. I08, I39 P. 2d 202 (I943); People v. Roppolo, 263 App. Div. 995, 33 N.Y.S. $2 d 257$ (1942); State v. Cook, 227 Iowa 1212 , 290 N.W. 550 (I940); People v. Warner, 289 Mich. 5I6, 286 N.W. 8 II (I939); State v. Ruzzo, 63 R.I. I38, 7 A. 2d 693 (r939); People v. Sherwood, 27I N.Y. 427, 3 N.E. 2d 58I (1936); State v. Matthews, Igr N.C. 378, I3I S.E. 743 (1926); Hackett v. People, 8 Colo. 390, 8 Pac. 574 ( $x 885$ ); State v. Gill, I4 S.C. 4 10 (r880).

xs State v. Gill, I4 S.C. 4 Io (I880); United States v. Krulewitch, I67 F. 2d 943 (C.C.A. 2d, r948); State v. Cook, 227 Iowa I212, 290 N.W. 550 (I940); United States v. Parker, ro3 F. $2 d$ 857 (C.C.A. 3d, x939); State v. Knight, 34 N.M. 222, 279 Pac. 947 (x929); State v. Sweat, 159 La. 769, 106 So. 298 (1925); State v. Murrel, 33 S.C. 83 , Ir S.E. 682 (1890). It was held in State v. Block, I I9 N.J.I. 277,196 Atl. 225 ( 1938 ) and State v. Jones, 74 S.C. 456,54 S.E. IOI 7 (IgO6) that such statements were not error, but in both cases the court made it clear that the jury's recommendation was not binding.

${ }^{16}$ State v. Doucet, ${ }_{77}$ La. 63 , ${ }_{47}$ So. 500 (I933); State v. Kernan, I54 Iowa 672, 135 N.W. 362 (1912); State v. Rowell, 224 N.C. 768, 32 S.E. 2 d 356 (1944); James v. State, 77 Okla. Cr. 108, 139 P. 2d 202 (1943); People v. Roppolo, 263 App. Div. 995, 33 N.Y.S. 2d 257 (1942); State v. Ruzzo, 63 R.I. x38, 7 A. 2d 693 (I939); People v. Warner, 289 Mich. 5I6, 286 N.W. 8II (I939); People v. Sherwood, 27I N.Y. 427, 3 N.E. 2d 58I (I936); State v. Matthews, x9I N.C. 378 , r3 I S.E. 743 (I926); Territory v. Griego, 8 N.M. I33, 42 Pac. 8 I (r895); Hackett v. People, 8 Colo. 390,8 Pac. 574 (1885). 
case it was possible that jurors were so influenced, and as long as that possibility does exist in any case where the evidence is not convincing, the defendant's right to an acquittal is seriously threatened.77

Although it would tend to discourage speculation about punishment, taking away the jury's right to recommend mercy is not desirable; for the ability to make such a recommendation tends to dispel any fears the jury may have about a harsh penalty and to prevent them from acquitting defendants of whose guilt they are certain. Protection of the defendant's rights, on the other hand, requires strict control of the jury by the trial court, chiefly by clear, unambiguous instructions. When a judge instructs the jury on reasonable doubt, he should make a special effort to make his instructions clear. ${ }^{18}$ When the jurors return to the court room after deliberating for several hours and ask whether they may recommend clemency, it becomes even more important that the court's instructions be intelligible. For in this situation it is probable that the jurors have doubts about the defendant's guilt, although it is also possible that they are convinced of his guilt but wish to recommend leniency because of extraneous circumstances. When the jurors return with such a request the court could inquire as to their motive in making it. If they indicate that they have agreed on the defendant's guilt, it would seem proper for the court to instruct them that they might recommend mercy, being careful to explain that such a recommendation is not binding. As a measure of caution, it should emphatically be stated that the degree of punishment is not a factor to be considered in determining the defendant's guilt or innocence. But if the judge detects that the jurors are inspired by a different motive-if it appears that they are reluctant to convict the defendant unless they can feel assured that the penalty will not be severeit would probably be safer if their request were refused. In Instead, they should

${ }^{17}$ Even where a juror has admitted that he was induced to agree to a verdict of guilty because he believed a recommendation of mercy would be binding, an affidavit to that effect could not be introduced to impeach the verdict. Roberts v. State, I54 Fla. 36, I6 So. 2d 435 (1944); State v. Bennet, 40 S.C. 308 , I8 S.E. 886 ( 1894 ). In the former case a juror filed an affidavit claiming that the jury had unanimously agreed that the facts did not justify an absolute verdict of guilty, but that they also felt that the defendant should be reprimanded. Believing that any recommendation they made would be binding on the court, the jury brought in a verdict of guilty and recommended a suspended sentence. It was asserted in the affidavit that the jury would not have found the defendant guilty had they known the real effect of their recommendation.

${ }^{88}$ As to the difficulty of giving clear instructions on reasonable doubt, see 9 Wigmore, Evidence $\$ 2497$ (3d ed., I940).

99 If the jury's explanation of why it wishes to recommend clemency is ambiguous, the court's task of ascertaining the jury's motive will obviously be made more difficult. However, the authority to exercise wide discretion in determining whether a recommendation should be permitted would enable a judge to be guided by his experience and by his own view of the evidence. For example, if he felt that the evidence was clearly against the defendant, he could reasonably conclude that in all probability the jury wanted to recommend leniency because of extraneous circumstances, and he could therefore allow them to accompany their verdict with a recommendation. If the judge was in doubt about the evidence, however, he would be justified in assuming that the jury was also in doubt, but that they would convict if they felt that the defendant would be given a light sentence. The procedure suggested would help to 
be reinstructed on the theory of "reasonable doubt," and only after a verdict of guilty has been returned should they be told of their right to recommend mercy. ${ }^{20}$

When juries are permitted to make recommendations of mercy, speculation on the punishment can not be entirely avoided, although proper control by the court can confine the degree of speculation to a minimum. But in several jurisdictions juries have been authorized by statute to determine the quantum of punishment, ${ }^{2 x}$ and in these states there is no method by which juries may be so controlled. The ability to impose a light sentence obviously makes it less difficult for a reluctant jury to concur in a verdict of guilty where the evidence is not thoroughly convincing, ${ }^{22}$ and these statutes are therefore contrary to the

protect the defendant's right to an acquittal where there is a reasonable doubt as to his guilt by limiting the jury's right to recommend mercy to cases where no such doubt exists.

${ }^{20}$ This would probably require an act of the legislature in those states in which recommendations of mercy are authorized by statute. But where no statutory authority exists, there is nothing to prevent the adoption of this procedure by the courts.

Consideration of punishment by juries obviously can not be completely avoided, and it is conceivable that there are circumstances in which their knowledge of the penalty might protect, rather than threaten, a defendant's rights. If a jury assumes, for example, that the penalty is light, in a doubtful case they will probably convict. But if the law requires a heavy sentence, and if the jury knows it, there will be a greater likelihood of acquittal, which is the desirable result if the defendant's guilt has not been proved beyond a reasonable doubt. Although it has been maintained here that knowledge of the penalty should be kept from juries, the problem arises as to what should be done in situations where knowledge of the penalty works for the defendant's protection. The dilemma can be avoided, where there is no definite penalty for a particular crime, by requiring trial courts to inform juries that the sentence is indeterminate. Since there are comparatively few crimes for which the statutory punishment is determinate, juries could be prevented from learning what the penalty will be and also from incorrectly assuming that it will necessarily be either light or severe.

${ }^{2 x}$ Ala. Code Ann. (Michie, r940) tit. I5, \& 335; Ark. Stat. (Pope, r937) \& 4039; Ga. Code (x948) $\delta \S 27-2501,27-2502$; Ill. Rev. Stat. (I947) c. 38, $\$ 754 a$; Ind. Stat. Ann. (Burns, I933) § 9-I819; Ky. Rev. Stat. Ann. (Baldwin, I948) § 43I.I30; Mo. Rev. Stat. (r939) \& 4092; Mont. Pen. Code (1935) § I 2027; N.D. Rev. Code (1943) \& I2-0605; Okla. Stat. (I94I) tit. 22, \$ 926; Tenn. Code Ann. (Michie, r938) \& I1766; Tex. Ann. Code Crim. Proc. (Vernon, I94I) Art. 693; Va. Code Ann. (Michie, x942) \& 49r9. The statutes cited give juries complete discretion in fixing the punishment within specified limits. Most other states have statutes authorizing juries in certain cases to determine which of two penalties should be inflicted. In first degree murder cases, for example, the jury may, by recommending mercy, automaticalIy reduce the death penalty to life imprisonment. Cal. Pen. Code (Deering, I94I) \& IgO; Colo. Stat. Ann. (Michie, r935) c. 48, § 32; Fla. Comp. Gen. Laws Ann. (Skillman, I941) $\S 919.23$ (2); Ga. Code (I948) \$§ 26-I005, 27-2302; Idaho Code Ann. (I948) \& 18-4004; Iowa Code (r946) \& 690.5; Kan. Gen. Stat. (Corrick, r935) \& 21-403; La. Code Crim. Proc. Ann. (Dart, I943) Art. 409; Md. Ann. Code (I939) Art. 27, §48x; Miss. Code Ann. (I942) §§ 2217, 2536; Mont. Rev. Codes Ann. (Darlington, I935) \& 10957; Neb. Rev. Stat. (r943) \& 28-401; Nev. Comp. Laws (Hilyer, I929) $\$$ I0068; N.H. Rev. Laws (1942) c. $455, \S 4$; N.J. Rev. Stat. (I937) tit. 2, c. I38, \& 4; N.Y. Pen. Code (McKinney, I944) § I045a; Ohio Code Ann. (Throckmorton, I948) \& I2400; Okla. Stat. (I94I) tit. 2I, \$ 707; Ore. Comp. Laws Ann. (I940) \& 234II; Pa. Stat. Ann. (Purdon, I930) tit. I8, \& 470I; S.C. Code of Laws (I942) tit. 2I, $\$$ IIO2; Tenn. Code Ann. (Michie, I938) \$\$ I077I, I0772; Wash. Rev. Stat. Ann. (Remington, 1932) \$ 2392; W.Va. Code Ann. (I943) § 6204; Wyo. Rev. Stat. Ann. (I945) \& 9-20I.

${ }^{22} \mathrm{~A}$ jury which determines the punishment may not always impose a light sentence, however, since a minimum period is often fixed by statute. In Illinois, for example, the minimum 
whole idea underlying the doctrine of reasonable doubt. Furthermore, juries are more easily influenced by emotional factors than judges, who, due to their experience, are better able to make an objective determination of the penalty to be inflicted. But perhaps the most vital objection to permitting juries to fix the punishment is that it tends to interfere with the effective administration of the parole system. In those jurisdictions in which it is the jury's duty to determine the punishment it would seem that they should be allowed to consider the effect of the parole laws, for punishment cannot be intelligently imposed without full knowledge of the actual amount of time that the defendant will remain incarcerated..$^{23}$ Parole statutes and laws which allow a reduction of sentence for good behavior make it possible for many prisoners to be released after serving from one-third to one-half their original term. ${ }^{24}$ In many jurisdictions a certain mini-

penalty for murder is fourteen years and it could not reasonably be maintained that a jury in a murder case had agreed to convict only because they felt that the penalty was light. Ill. Rev. Stat. (I947) c. $38, \$ 360$. Such a possibility would exist in rape cases, however, where the minimum penalty is one year. Ill. Rev. Stat. (r947) c. $38, \$ 490$.

${ }^{23}$ State v. Barth, II4 N.J.L. II2, I76 Atl. I83 (I935); Massa v. State, 37 Ohio App. 532, I75 N.E. 219 (I930); State v. Mosley, ro2 N.J.L. 94, I3 I Atl. 292 (I925); State v. Schilling, 95 N.J.L. I45, II2 Atl. 400 (I920); State v. Martin, 94 N.J.L. r39, Iog Atl. 350 (I920); State v. Carrigan, 93 N.J.L. 268, xo8 Atl. 355 (I9x9); State v. Rombolo, 89 N.J.L. 565, 99 Atl. 434 (I9I6); 9 o U. of Pa. L. Rev. 22I (I94I), noting Sukle v. People, ro7 Colo. 269, III P. 2 d 233 (r94I); 5 I Harv. L. Rev. 353 (I938), noting State v. Carrol, 52 Wyo. 29, 69 P. $2 d$ 542 ( 1937 ). It is maintained, in opposition to this view, that the defendant is prejudiced when the jury is permitted to speculate on the possibility of parole, since they are likely to fix a greater penalty than they otherwise might have considered. Sukle v. People, xo7 Colo. 269, III P. 2d 233 (I94); Houston v. Commonwealth, 270 Ky. I25, Io9 S.W. 2d 45 (I937); Bean v. State, 58 Okla. Cr. 432, 54 P. 2d 675 (I936); Coward v. Commonwealth, I64 Va. 639, I 78 S.E. 797 (I935); Gaines v. Commonwealth, 242 Ky. 237, 46 S.W. 2d 75 (I932); Postell v. Commonwealth, I74 Ky. 272, 192 S.W. 39 (I9I7); State v. Dooley, 89 Iowa 584, 57 N.W. 4I4 (r894). Since the death penalty has been imposed where the court has refused the jury's request for an instruction on the effect of the parole statutes, this contention appears to be unfounded. Gaines v. Commonwealth, 242 Ky. 237,46 S.W. $2 d$ 75 (I932); State v. Dooley, 89 Iowa 584,57 N.W. $4 \mathrm{I} 4$ (1894). Also, since most courts have held that it is not prejudicial error for the prosecuting attorney to mention the possibility of parole in his argument before the jury, it is difficult to see how the defendant could be prejudiced by a remark to the same effect by the court. Underwood v. Commonwealth, $266 \mathrm{Ky}$. 6x3 99 S.W. 2 d 467 (I937); Sullivan v. State, 47 Ariz. 224, 55 P. 2d 3 I2 (r936); Glenday v. Commonwealth, 255 Ky. 3 I3, 74 S.W. 2 d 332 (1934); State v. Stratton, x 70 Wash. 666, I7 P. 2d 621 (1932); People v. Murphy, 276 Ill. 304 , II4 N.E. 609 (I916); Hillen v. People, 59 Colo. 280, I49 Pac. 250 (I9I5); Jacobs v. State, I03 Miss. 622, 60 So. 723 (I912); Wechter v. People, 53 Colo. 89, I24 Pac. I83 (I9x); State v. Junkins, $x_{47}$ Iowa 588, I26 N.W. 689 (I9I0); see 90 U. of Pa. L. Rev. 221 (r94I), noting Sukle v. People, ro7 Colo. 269, rrI P. 2d 233 (r94I); 5x Harv. L. Rev. 353, noting State v. Carrol, 52 Wyo. 29, 69 P. $2 \mathrm{~d} 542$ (I937). Contra: State v. Johnson, I5I La. 625,92 So. I39 (r922).

24 Depending on the length of the sentence, as many as fifteen days may be deducted for good behavior for every month that a prisoner spends in the penitentiary. Cal. Pen. Code (Deering, I94I) § 2920; Colo. Stat. Ann. (Michie, 1935) c. 48, § 556; Conn. Gen. Stat. (I949) $\S 3002$; Ky. Rev. Stat. Ann. (Baldwin, 1948) \& r97.040; Ind. Ann. Stat. (Burns, I933) \& $x_{3}-$ II6; Md. Ann. Code (Flack, Supp. x947) Art. 27, \& 770; Mich. Stat. Ann. (Henderson, x938) \$ 28-I403; Mont. Rev. Codes Ann. (Anderson \& McFarland, x935) § I2455; N.D. Rev. Code (1943) § I2-540r; Okla. Stat. Ann. (I94I) tit. 57, § 138; Tenn. Code Ann. (Michie, 1938) $\$$ I2209(I); Tex. Ann. Rev. Stat. (Vernon, I94I) Art. 6r66v; Va. Code Ann. (Michie, I942) $\S 5$ or 7 . 
mum period varying with the length of the sentence must be served before a parole can be obtained, ${ }^{25}$ and it is therefore possible for juries to evade the purpose of these statutes and greatly limit the discretion of parole boards by first determining that a just punishment for a particular crime is ten years and by then sentencing a defendant to twenty. ${ }^{26}$ Since it is within the power of a judge to do the same thing when the court determines the punishment, this is not a sufficient reason for withdrawing the sentencing power from juries; but recognition of the ability to circumvent the effect of parole statutes makes apparent a basic conflict in our entire sentencing procedure. Two agencies-courts (or juries) and parole boards-have been given the authority to determine the one question of how long a particular prisoner should be confined. Judges and juries can not intelligently pass sentence without considering the effect of parole statutes, and yet in so doing they have the power to limit the operation of these statutes and greatly weaken the authority of boards of parole. Probably the best solution to this problem, and that most consistent with modern theories of individualized punishment, would be to take the sentencing power completely away from the courts and to confer the authority to fix punishments on the same agency which has control of paroles. ${ }^{27} \mathrm{~A}$ step in this direction has been

25 Del. Rev. Code (r935) § 4I50; Ky. Rev. Stat. Ann. (Baldwin, I948) § r97.040; La. Code Crim. Proc. Ann. (Dart, 1943) \& 725.2; Mont. Rev. Codes Ann. (Anderson \& McFarland, r935) § r 2264 (2); Ill. Rev. Stat. (1947) c. 38 , § 8or; Va. Code Ann. (Michie, r942) \&4788h.

No states allow parole boards complete discretion as to when paroles may be granted. Where the minimum period is not a certain fraction of the total sentence, it is usually provided that before a prisoner may be paroled he must serve the minimum sentence for the particular crime which he has committed. For example, if the penalty for burglary is from five to twenty years at the discretion of the court (or jury), no parole could be granted to one convicted of that crime before he had served five years (less time off for good behavior). Where such a provision is in effect, it is not possible for a court or jury to extend the minimum period that must be served before a parole can be obtained. Ariz. Code Ann. (r939) $\$ \S 44-3006$, 44-3010; Colo. Stat. Ann. (Michie, 1935) c. 48, § 547; Conn. Gen. Stat. (I949) § 8827; Kan. Gen. Stat. (Corrick, I935) §62-1525; Minn. Stat. (Mason, x945) §637.0I; Nev. Comp. (Hilyer, I929) § I 1059; N.D. Rev. Code (I943) § I 2-5509; N.M. Stat. Ann. (I94r) § 42-I 706; Tenn. Code Ann. (Michie, I938) § xr77r.

${ }^{26}$ Coward v. Commonwealth, 164 Va. 639 , 178 S.E. 797 (1935).

${ }_{27}$ This has actually been done in California and Iowa, where the courts fix no period of confinement at all, although the parole board may not release a defendant before he has served the statutory minimum, nor detain him after he has served the maximum sentence for the particular crime which he has committed. Cal. Pen. Code (Deering, I94I) $\$$ II68, 3020, 3023 ; Iowa Code ( 1946$) \S \S 247.5,789.13$. There has been some indication that prisoners themselves oppose indeterminate sentence provisions because they fear the arbitrary exercise of power by parole officials. 7 Calif. L. Rev. 132, I35 (1919), noting Ex Parte Bouchard, 38 Cal. App. $44 \pi, 176$ Pac. 692 (I9I8).

The constitutionality of indeterminate sentence statutes has been questioned on the ground that they unlawfully delegate a judicial function to an administrative agency. Their constitutionality has generally been upheld, however. 24 Harv. L. Rev. 236 (r9ro), noting People v. Joyce, 246 Ill. x 24, 92 N.E. 607 (IgIO).

Retribution as the main purpose of punishment is gradually being replaced by theories which tend to emphasize reform of the individual. The belief that the punishment should fit the crime is giving way to the idea that the treatment should fit the character and habits of the offender; and, since the disposition of offenders under modern views requires extensive investigation by experts in fields other than the law, the suggestion has been made that 
taken in those jurisdictions where statutory provision has been made for indeterminate sentences..$^{28}$ Unfortunately, in some of these states it is the jury which fixes the minimum and maximum penalty. ${ }^{29}$

As long as the authority to impose punishment is not given to a separate agency, it would seem desirable that this function be kept within the exclusive power of the court $3^{30}$ for three reasons. The first is that although both court and jury, when they fix the penalty, can limit the parole board's discretion as to when a particular prisoner should be released, the former would be less likely to do so. ${ }^{3 \mathrm{x}}$ Judges are in a better position to understand the operation and aims of the parole system and to limit their own authority accordingly when passing sentence. Secondly, determination of punishment by juries is contrary to the rule of reasonable doubt. Finally, the task of fitting the punishment to the individual offender requires some knowledge of the defendant's character and background. Several jurisdictions permit juries to hear evidence of the accused's

separate tribunals be given the power to determine completely the type and degree of treatment. Nat'l Com. on Law Observance and Enforcement, Report on Penal Institutions, Probation and Parole I70-74 (I93I); Report of the Cincinnati Conference On Criminal Law Administration, 9 U. of Cin. L. Rev. 404, 405 (1935). In answer to a questionnaire at the Cincinnati conference, twenty-seven persons stated that the court should fix the punishment, whereas fifty-five preferred that a special treatment tribunal have complete control over the disposition of offenders. 9 U. of Cin. L. Rev. 472 (1935). See Pound, Criminal Justice in the American City, in Criminal Justice In Cleveland 587-89 (I922), on changed ideas regarding the purpose of punishment.

${ }^{28}$ Ariz. Code Ann. (I939) § 44-2233; Colo. Stat. Ann. (Michie, I935) c. 48, § 545; Conn. Gen. Stat. (I949) § 8825; Idaho Code Ann. (I948) \& I9-25I3; Me. Rev. Stat. (I944) c. I36, $\S \mathrm{II}$; Mich. Stat. Ann. (Henderson, I938) § 28.1080; Nev. Comp. Laws (Hilyer, I929) $\S$ Ir058, I1059; N.J. Rev. Stat. (r937) tit. 2, c. I92, \& 4; N.H. Rev. Laws (1942) c. 429, $\S 20 ;$ N.Y. Pen. Code (McKinney, I944) § 2819; N.D. Rev. Code (I943) \& 12-0607; N.M. Stat. Ann. (I94r) \& 42-170r; Tex. Ann. Code Crim. Proc. (Vernon, I94I) art. 693. In Illinois the penalty in murder, kidnapping, and rape cases is a definite term to be fixed by the jury, and one-third of that term must be served before a prisoner is eligible for parole. In all other cases the sentence is indeterminate and the minimum and maximum penalties are set by the judge. To become eligible for parole under an indeterminate sentence a prisoner must serve at least the minimum period as determined by the court. Ill. Rev. Stat. (I947) c. $3^{8}$ $\S \S 754,801,802,807$.

29 Ga. Code (1948) § 27-2502; Tenn. Code Ann. (Michie, r938) § II766.

30 "Overburdening juries by adding to their task of finding the facts tasks of finding the law and of assessing the punishment have made for loss of faith in the common-law mode of trial in the jurisdictions where these practices obtain. It is significant that there is most satisfaction with criminal juries in those jurisdictions which have interfered least with the conception of a trial of the facts by jurors unburdened with further responsibility. ... The remedy for the conspicuous abuses of the jury trials . . . is to be found in less and more rational use of the jury, [and] in confining the jury to the work of fact-finding. ..." Nat'l Com. on Law Observance and Enforcement, op. cit. supra note 5, at 23-28. See 9 U. of Cin. L. Rev. 403, 404 (1935); Missouri Ass'n for Crim. Justice, The Missouri Crime Survey I82, 366 (I926).

${ }^{3 x}$ It appears that the contrary is true in Illinois, however, where the range between minimum and maximum penalties fixed by judges has been too short to allow the parole board any discretion in determining when prisoners should be released. Blackiston, Previous Criminal Records and the Indeterminate Sentence, 76 Crim. Justice 27, 33 (1948). 
past history so that they may impose an appropriate penalty, ${ }^{3 z}$ but this procedure greatly increases the possibility that the verdict will be influenced by factors not relevant to the question of the defendant's guilt or innocence. ${ }^{33}$

When the court imposes punishment the jury must be discouraged from acquitting defendants whose guilt is certain but whom they are unwilling to convict because they fear that the penalty will be too harsh. Permitting the jury to recommend mercy is therefore desirable, since it would tend to eliminate that fear. Yet if the rule of reasonable doubt is to be adhered to, either juries must be more strictly controlled in making recommendations of mercy, or it must be admitted that the policy of the law has changed and that in doubtful cases it is now preferable to convict defendants and allow jurors to ease their consciences in so doing by convincing themselves that the penalty will be light.

\section{IIMITATIONS ON THE AVAILABILITY OF SPECIFIC PERFORMANCE}

Normally the damages which are awarded for breach of contract are intended to put a plaintiff in as good a position as he would have been in had the agreement been carried out. Such expectation damages insure a rough measure of compensation for hard-to-prove or hard-to-measure elements of reliance and for the distress and insecurity which result from failure to keep promises. In addition, good guesses about future needs in our free enterprise economy are rewarded. One would therefore naturally expect that the plaintiff would be given, whenever possible, an exact equivalent of performance, rather than its approximation in damages. ${ }^{1}$ Yet specific performance remains an extraordinary remedy because of the rules defining the jurisdiction of the chancellor and those limiting the exercise of his power. The law of Illinois, as elsewhere, has been most troubled by the doctrines concerning the adequacy of legal remedy, extended performance, mutuality of remedy, and the enforcement of "negative" promises.

\section{I}

Inadequacy of the remedy at law is the basis for equitable jurisdiction to decree specific performance. ${ }^{2}$ From this premise the courts have developed a I940).

${ }^{32}$ Ill. Rev. Stat. (1947) c. $38 \$ \S 473,602$; see I Wigmore, Evidence, $\S$ Ig6(2)(b) (3d ed.,

${ }^{33}$ This difficulty has been avoided in some states by permitting the jury to hear evidence of the defendant's background and past convictions only after their verdict has been returned. I Wigmore, Evidence $\S$ Ig6(2)(a) (3d ed., r940).

${ }^{1}$ On the theory of contract damages see Sharp, Promissory Liability. I, 7 Univ. Chi. L. Rev. I, 17 (1939); Fuller and Perdue, The Reliance Interest in Contract Damages, 46 Yale L.J. 52 (1936), 46 Yale L.J. 373 (1937).

2 Maitland, Equity 30r (2d ed. I936); 2 Story, Equity Jurisprudence $\S 993$ (r4th ed. I9I8). 